\title{
Determinants of the quality of life among pre-elderly and elderly population
}

\author{
Jasrida Yunita, Nurlisis Nurlisis, Wulan Sari \\ School of Health Hang Tuah Pekanbaru, Indonesia
}

\begin{tabular}{l}
\hline Article Info \\
\hline Article history: \\
Received Jun 9, 2019 \\
Revised Jul 20, 2019 \\
Accepted Aug 21, 2019 \\
\hline
\end{tabular}

\section{Keywords:}

Chronic disease, Elderly

Sex

Quality of life

\begin{abstract}
Health problems will appear along with the increasing aging of someone that can reduce the quality of life. Many factors can decreases in quality of life. The purpose of this study was to find the determinants of the quality of life to the pre-elderly and elderly population in the working area of Harapan Raya public health center Pekanbaru, Riau, Indonesia. The design of the research was cross sectional in the pre-elderly population (45-59 years) and the elderly population (60 years and above). There were 103 respondents participated in this study gathared with consecutive sampling techniques. Quality of life was measured using WHOQOL SF-36 questionnaire. Independent variables were body mass index, physical activity, chronic disease, smoking behavior, employment status, residence status, marital status, education, age, and sex. Data were analyzed by univariate, bivariate with Chi square test, and multivariate with multiple logistic regression. The proportion of subjects with low quality of life was $18.4 \%$. Variables related to bivariate were body mass index, smoking behavior, chronic disease, employment status, and sex. Chronic disease (OR=5.5; 95\% $\mathrm{CI}=1.173-25.674)$ significantly affected the quality of life after being controlled by sex. The quality of life could be explained by this factor about $17 \%$. It is necessary to manage chronic diseases in the public health center and provide information to the pre-elderly and the elderly through counseling, print and electronic media.
\end{abstract}

Copyright $@ 2019$ Institute of Advanced Engineering and Science. All rights reserved.

\section{Corresponding Author:}

Nurlisis,

School of Health Hang Tuah Pekanbaru,

Jalan Mustafa Sari No. 5 Tangkerang Selatan Kota Pekanbaru, Riau Indonesia.

Email: isis.webby@gmail.com

\section{INTRODUCTION}

Indonesia is one of the top five countries with the largest number of elderly people in the world, reaching 18.1 million or 7.6 percent of the total population. Based on data from the 2013 Central Bureau of Statistics projecting, the number of elderly people $(60+)$ is expected to increase to 27.1 million by 2020 , to 33.7 million in 2025 and 48.2 million in 2035 [1].

More increase of age, the more likely a person has problems, such as physical, mental, spiritual, economic and social. One of the most basic problems in the elderly is a health problem due to the degenerative process; this is indicated by data on disease patterns in the elderly. Based on the 2013 Basic Health Research (Riskesdas), the most prevalent diseases in the elderly were non-communicable diseases including hypertension (57.6\%), arthritis $(51.9 \%)$, stroke $(46.1 \%)$, dental and oral problems $(19.1 \%)$, chronic obstructive pulmonary disease $(8.6 \%)$ and diabetes mellitus $(4.8 \%)$ [1].

Meanwhile with increasing age, functional disorders will increase so that it will affect the quality of life of the elderly. Quality of life is a broad concept that is influenced in a complex way by physical health, psychological state, level of independence, social relations, individual beliefs and their relationship with environment [2]. 
In the elderly, a person will experience changes in physical, psychological, social, and environmental aspects [2-3]. If the physical, psychological, social, and environmental are not fulfilled, problems will arise in the elderly life that will reduce the quality of life. The main factors considered to be related to quality of life in older people include dementia and depression [4-5]. The elderly are also very susceptible to malnutrition, which is also a factor in the declining quality of life of the elderly, can be measured by looking at the nutritional status/elderly body mass index (BMI) [6-8]. In addition, the factor of staying with family [9], chronic diseases [7], physical activity [10-12] health behavior [13], including individual characteristics can also affect the quality of life of the elderly.

Actually not always the quality of life decreases when entering the elderly. About $68 \%$ of the quality of life of elderly people is high [1]. But it would be better if we know the factors that affect the quality of life of the elderly so that it can be prevented from the rapid decline of the condition of the elderly. Quality elderly are healthy, independent, active and productive.

The growth of the elderly in Pekanbaru is also quite high. Based on the Health Profile of Pekanbaru City 2016 there were $4.6 \%$ of the elderly of the entire population, who received health services around $60.58 \%$ its decrease if it is compared to 2015 of around $63.21 \%$. Of all the health centers in Pekanbaru City, the majority of elderly people are in Harapan Raya Health Center (9,718 people) [14].

\section{RESEARCH METHOD}

This research was quantitative study employed Cross Sectional design. The study was conducted in the working area of Harapan Raya Health Center, Pekanbaru City Health Office. The time of research for approximately one year can be completed. The population in this study was all elderly who were recorded in Harapan Raya Health Center totaling 9718 people. The sample in this study was 103 people.

The sampling technique uses consecutive sampling technique, the sample is chosen based on predetermined criteria. Sampling was carried out in Integrated Service Post (Posyandu), Integrated Development Post (Posbindu), and Public Health Center (Puskesmas) until the number of samples was fulfilled. Before data collection is done, the questionnaire is tested first through validity and reliability. Data processing includes editing, coding, processing, cleaning, and tabulating. Data analysis was carried out in stages which included univariate, bivariate, and multivariate analysis.

Before the study began, the researcher arranged a research permit to the agency authorized to issue a research permit. Next, the researcher conducted an ethical test at the Health Research Ethics Committee of Institute of Health Science in Hang Tuah Pekanbaru. After obtaining ethical permission, new researchers took to the field to collect data. Before conducting an interview with the respondent, the researcher first asks the informant for approval through the Informed Consent.

Retrieval of quality of life data in this study using instrument questionnaire that is subjective so that it can cause bias. The questions in the questionnaire relate to the feelings and satisfaction of the subject to aspects of physical health so that it is subjective.

\section{RESULTS AND DISCUSSIONS \\ Chronical disease}

Based on the results of the study, most of the subjects suffered chronic diseases as many as 67 elderly (59.2\%) including 17 elderly (25.4\%) who have low quality of life and 50 elderly (48.54\%) have a good quality of life. Subject is too rarely experience physical complaints that hinder activity. Multivariate analysis results indicate that there is a relationship statistically significant $(p<0.05)$ between the incidence of chronic illness and quality life dimension of physical health. The elderly who have chronic disease are at 5.5 times the risk of having a lower quality of life compared to the elderly with no history of chronic disease. Most of the subjects had chronic diseases as many as 67 people, who had a low quality of life as many as 17 people and most suffered from hypertension. Chronic disease in question is a disease that has been diagnosed by a doctor and has suffered for at least three months [15]. Chronic diseases found in subjects including hypertension, diabetes mellitus, gout, heart disease, chronic lung disease, and chronic gastritis.

With increasees of age, disruption of organ systems and the immune system often results in the emergence of various degenerative diseases and the emergence of infect serious diseases. Such as hematological disorders, hypertension, cardiovascular disease, digestive system diseases, endocrine diseases, rheumatism, infections. Chronic illnesses affect quality of life because they can limit individuals from carrying out activities they consider important. The existence of chronic diseases also interferes with the control of one's feelings towards him. Someone with a chronic illness tends to compare their condition with others who are healthier. This is consistent with previous research which states that the 
quality of life of the physical and environmental domains in the elderly who experience chronic disease are lower in quality of life, significantly compared to the elderly who do not experience chronic disease. These results indicate that the quality of life in elderly outpatients with chronic diseases is influenced by many factors such as health, as well as social factors and other factors [16-17]. The elderly must improve quality of life by improving health every day, balanced menus, light exercise, and do physical activities, do some fun hobbies, and also think optimistically about health condition [18].

\section{Sex}

The number of elderly female is more than the elderly male. 19 people (18.4\%) have low quality of life; many elderly women $(89.5 \%)$ have a lower quality of life compared to older men $(10.5 \%)$. Multivariate analysis results that gender variable are relationship statistically significant. The elderly female at 4 times have a lower quality the elderly with male. The results of this study are in line with studies conducted by Henderson et al. Which show that polypharmacy has a relationship with the quality of life of the physical health component even after controlling for age, sex, and chronic disease. The majority of elderly women have more self-reported chronic diseases and a higher average body mass index [19].

Table 1 shows that of the 103 elderly below shows that, of the 103 elderly who experienced a poor quality of life of the elderly as many as 19 people (18.4\%) and a good quality of life of 84 people (81.4\%). Bivariate analysis of the quality of life of the elderly and the factors that influence it in the work area of Harapan Raya Health Center in this study there are ten variables which can be seen in Table 2, indicating that out of 10 independent variables there are three variables that are significantly $(p<0.05)$ with life is nutritional status, chronic illness and work. The final multivariate results found that chronic disease and sex are at risk of having a low quality of life for the elderly as shown in Table 3.

Table 1. Distribution of supporting variables about quality of life for erderly and its affecting factors

\begin{tabular}{|c|c|c|}
\hline \multirow{2}{*}{ Independent Variable } & \multicolumn{2}{|c|}{ Total } \\
\hline & $(n=155)$ & $(100 \%)$ \\
\hline \multicolumn{3}{|l|}{ Quality of Life for Erderly } \\
\hline Low & 19 & 18.4 \\
\hline High & 84 & 81.4 \\
\hline \multicolumn{3}{|l|}{ Body Mass Index (BMI) } \\
\hline Abnormal & 38 & 36.9 \\
\hline Normal & 65 & 63.1 \\
\hline \multicolumn{3}{|l|}{ Chronic Disease } \\
\hline 0-2 Disease & 67 & 65 \\
\hline$>2$ Disease & 36 & 35 \\
\hline \multicolumn{3}{|l|}{ Physical Activity } \\
\hline No Exercise & 88 & 85.4 \\
\hline Exercise & 15 & 4,6 \\
\hline \multicolumn{3}{|l|}{ Smoking Behavior } \\
\hline Smoking & 8 & 7.8 \\
\hline Occasionally Smoking & 16 & 15.5 \\
\hline Never Smoke & 79 & 76.7 \\
\hline \multicolumn{3}{|l|}{ Employement Status } \\
\hline Unemployee & 81 & 78.6 \\
\hline Employee & 22 & 21.4 \\
\hline \multicolumn{3}{|l|}{ Family structure } \\
\hline Alone & 7 & 6.8 \\
\hline With Family & 96 & 93.2 \\
\hline \multicolumn{3}{|l|}{ Marital status } \\
\hline Divorce & 33 & 32 \\
\hline Married & 70 & 68 \\
\hline \multicolumn{3}{|l|}{ Father Education } \\
\hline low & 51 & 49.5 \\
\hline Hight & 52 & 50.5 \\
\hline \multicolumn{3}{|l|}{ Sex } \\
\hline Famale & 72 & 69.9 \\
\hline Male & 31 & 30.1 \\
\hline \multicolumn{3}{|l|}{ Age } \\
\hline$\geq 60$ year & 77 & 78.4 \\
\hline $4 \overline{5}-60$ year & 26 & 25.2 \\
\hline
\end{tabular}

The result of this study is inline with another study about quality of life among the elderly Iranians. Multiple logistic regression analysis showed that for the gender, age, education and economic status were significant determinants of poorer physical health-related quality of life [20]. 
Table 2. Relationship between several supporting variables on the quality of life among the elderly

\begin{tabular}{|c|c|c|c|c|c|c|c|c|}
\hline \multirow{3}{*}{ Independent Variable } & \multicolumn{4}{|c|}{ Quality of Life for Erderly } & \multicolumn{2}{|c|}{ Total } & \multirow{3}{*}{ Pvalue } & \multirow{3}{*}{$\begin{array}{c}\text { POR } \\
(95 \% \mathrm{CI})\end{array}$} \\
\hline & \multicolumn{2}{|c|}{ Low } & \multicolumn{2}{|c|}{ High } & \multirow{2}{*}{$\mathrm{N}$} & \multirow{2}{*}{$(\%)$} & & \\
\hline & $\mathrm{N}$ & $(\%)$ & $\mathrm{N}$ & $(\%)$ & & & & \\
\hline \multicolumn{9}{|l|}{ Body Mass Index (BMI) } \\
\hline Less & 4 & $(65.2)$ & 4 & $(34.8)$ & 8 & $(100)$ & \multirow{3}{*}{0.010} & \multirow{3}{*}{$\begin{array}{c}32.188 \\
(11.577-89.493)\end{array}$} \\
\hline Normal & 7 & $(5.5)$ & 58 & $(94.5)$ & 65 & $(100)$ & & \\
\hline Obesity & 8 & $(26.7)$ & 22 & $(73.3)$ & 30 & $(100)$ & & \\
\hline Chronic Disease & & & & & & & \multirow{3}{*}{0.027} & \multirow{3}{*}{$\begin{array}{c}5.780 \\
(1.253-26.655)\end{array}$} \\
\hline Disease & 17 & $(40.0)$ & 50 & $(74.6)$ & 67 & $(100)$ & & \\
\hline No Disease & 2 & $(5.6)$ & 34 & $(94.4)$ & 36 & $(100)$ & & \\
\hline \multicolumn{9}{|l|}{ Physical Activity } \\
\hline No Exercise & 16 & $(18.2)$ & 72 & $(81.8)$ & 88 & $(100)$ & \multirow[t]{2}{*}{1.00} & \\
\hline Exercise & 3 & $(20.0)$ & 12 & $(80.0)$ & 15 & $(100)$ & & \\
\hline \multicolumn{9}{|l|}{ Smoking Behavior } \\
\hline Smoking & 1 & $(12.5)$ & 7 & $(87.5)$ & 8 & $(100)$ & \multirow{3}{*}{0.091} & \\
\hline Occasionally Smoking & 0 & $(0.00)$ & 16 & $(15.5)$ & 16 & $(100)$ & & \\
\hline Never Smoke & 18 & $(22.8)$ & 61 & $(77.2)$ & 79 & $(100)$ & & \\
\hline \multicolumn{9}{|l|}{ Employement Status } \\
\hline Unemployee & 19 & $(23.5)$ & 62 & $(76.5)$ & 81 & $(100)$ & \multirow[t]{2}{*}{0.027} & 0.765 \\
\hline Employee & 0 & $(0.00)$ & 22 & $(21.4)$ & 22 & $(100)$ & & \\
\hline \multicolumn{9}{|l|}{ Family Structure } \\
\hline Alone & 0 & $(0.00)$ & 7 & $(6.8)$ & 7 & $(100)$ & \multirow[t]{2}{*}{0.424} & \\
\hline With Family & 19 & (19.8) & 77 & (80.2) & 93 & $(100)$ & & \\
\hline \multicolumn{9}{|l|}{ Father Education } \\
\hline low & 10 & (19.6) & 41 & $(80.4)$ & 51 & $(100)$ & \multirow[t]{2}{*}{0.963} & \\
\hline Hight & 9 & (17.3) & 43 & $(82.7)$ & 52 & (100) & & \\
\hline \multicolumn{9}{|l|}{ Marital status } \\
\hline Divorce & 9 & $(27.3)$ & 24 & $(72.7)$ & 33 & (100) & \multirow[t]{3}{*}{0.189} & \\
\hline Married & 10 & (14.3) & 60 & (85.7) & 70 & (100) & & \\
\hline Usi Age & & & & & & & & \\
\hline$>=60$ year & 15 & (19.5) & 62 & $(80.5)$ & 77 & (100) & \multirow{3}{*}{0.863} & \\
\hline 45-60 year & 4 & (15.4) & 22 & (84.6) & 26 & (100) & & \\
\hline Sex & & & & & & & & \\
\hline Famale & 17 & (23.6) & 55 & (76.4) & 72 & (100) & 0.075 & \\
\hline Male & 2 & $(6.5)$ & 29 & (93.5) & 31 & (100) & & \\
\hline
\end{tabular}

Table 3. Final multivariate desain

\begin{tabular}{lccccc}
\hline \multicolumn{2}{c}{ Table 3. Final multivariate desain } \\
\multirow{2}{*}{ No } & Variabel & \multirow{2}{*}{ Pvalue } & \multirow{2}{*}{ POR } & \multicolumn{2}{c}{$(95 \% \mathrm{CI})$} \\
& & & Lower & Upper \\
\hline 1 & Chronic disease & .030 & 5.49 & 1.173 & 25.67 \\
2 & Sex & .071 & 4.20 & .885 & 19.89 \\
\hline
\end{tabular}

\section{CONCLUSION}

The proportion of subjects with low quality of life was $18.4 \%$. Chronic disease occurrence and sex are correlated with quality of life health in elderly at North Harapan Raya Community Health Center work area. This research shows that there is no meaningful relationship statistically between body mass index, physical activity, smoking behavior, employment status, marital status, family structure, father education and age. It is necessary to manage chronic diseases in the public health center and provide information to the preelderly and the elderly through counseling, print and electronic media. Monitoring of Prolanis program activities and integrated health center for the elderly also needs to be improved to monitor chronic diseases suffered by the community.

\section{REFERENCES}

[1] Ministry of Health, R. I., PMK No. 25 Regarding the National Action Plan for Elderly Health for 2016-2019, 2016.

[2] WHO., Program on WHOQOL Mental Health Measuring Quality of Life. Retrieved from http://www.who.int/mental_health/media/68.pdf, 1997.

[3] Rohmah, I. N., Anis, B., \& Khoridatul,. Quality of Elderly Life. Nursing Journal, 3 (2), $120-132$. https://doi.org/ISSN 2086-3071, 2012.

[4] Mauceri, M., \& Marco, O. L.G. In., Psychosocial Dimensions of Quality of Life among Elders: A Research of the Italian and Spanish Elderly. Procedia-Social and Behavioral Sciences, 116, 1651-1655. https://doi.org/10.1016/j.sbspro.2014.01.451, 2014. 
[5] Netuveli, G., \& Blane, D., Quality of life in older ages. British Medical Bulletin, 85 (1), $113-126$. https://doi.org/10.1093/bmb/ldn003, 2008.

[6] Islamiyah, Jafar, N., \& Hadju, V. Lifestyle, Nutritional Status and Quality of Life for Older People Still Working. Hasanuddin University, (8). 2013.

[7] Sari, N. K., \& Pramono, A., Nutritional Status, Chronic Poet, and Drug Consumption of the Quality of Life for Elderly Physical Health. Journal of Nutrition College, 3 (1), 83-89. Retrieved from http://ejournals1.undip.ac.id/index.php/jnc, 2014.

[8] WHO., Nutrition for older persons. Retrieved from http://www.who.int/nutrition/topics/ageing/en/index1.html, 2015.

[9] Putri, S. T., Fitriana, L. A., Ningrum, A., \& Sulastri, A. (207AD). Comparative Study: Quality of Life for Elderly People Living with Families and Homes. Indonesian Nursing Education Journal, 85, 1-6.

[10] Lok, N., Lok, S., \& Canbaz, M. The effect of physical activity on depressive symptoms and quality of life among elderly nursing homes: Randomized controlled trials. Archives of Gerontology and Geriatrics, 70, 92-98. https://doi.org/10.1016/j.archger.2017.01.008, 2017.

[11] Morris, M., \& Schoo, A., Optimizing Exercise and Physical Activity in Older People. Elsevier Science, 1-356. https://doi.org/10.1017/CBO9781107415324.004, 2004.

[12] Timisela, J. C., Ratag, B. T., \& Kalaskan, A. F. (2017). Relation of Physical Activity to Life Quality of Type II DM Patients in RSU Pancaran Kasih. Health Media, 9 (3), 1-6. Retrieved from https://ejournalhealth.com/index.php/medkes/article/view/311/303

[13] Rahardjo, T. B. W., Asir, A. N. Y., Kusdhany, L., Dewi, vita P., \& Agustin, D., Textbook "Introduction to Gerontology and Geriatrics as a Multi-Discipline Reference Book and for the Community.", 2014.

[14] Pekanbaru, D., Pekanbaru City Health Profile in 2016., 2017

[15] Wikananda, G. (2017). Relationship between quality of life and risk factors in the elderly in the working area of the puskesmas, in the district of Gianyar Bali, 2015. Summary of Medical Science, 8 (1), 1-12. https://doi.org/10.15562/ism.v8i1.112

[16] Robert A. Pearlman, Richard F. Uhlmann. Quality of Life in Chronic Diseases: Perceptions of Elderly Patients. Journal of Gerontology, Volume 43, Issue 2, March 1988, Pages M25-M30, https://doi.org/10.1093/geronj/43.2.M25

[17] Anis Ika Nur Rohmah, Purwaningsih, Khoridatul Bariyah. Quality of Life Elderly. Jurnal Keperawatan, ISSN 2086-3071. Volume 3, Nomor 2.2012

[18] Anugrahanti, W. W., \& Debora, O. Application Of Classification And Regression Tree (Cart) On Life Independency Based On Functional Capacity And Health Condition Of Older Adults In Kasin Village Bareng Health Center, Malang International Conference of Kerta Cendekia Nursing Academy. 2019 September; 1: 150-157. 2019. DOI. 10.5281/zenodo.337417. http://ejournal-kertacendekia.id/index.php/ICKCNA/.

[19] Tiago da Silva Alexandre ${ }^{\text {I; }}$ Renata Cereda Cordeiro ${ }^{\mathrm{II}}$; Luiz Roberto Ramos. Factors associated to quality of life in active elderly. SciELO-Scientific Electronic Library Online.2009.

[20] Maryam Tajvar, Mohammad Arab, Ali Montazeri. Determinants of health-related quality of life in elderly in Tehran, Iran. BMC Public Health, volume 8, Article number: 323, 2008. 